\title{
Research on Relevant Points in Building Indoor and Outdoor Environmental Art Design Teaching
}

\author{
Chuangang Li \\ Mudanjiang Normal University, Mudanjiang, 157001, China
}

\begin{abstract}
Keywords: environmental art design; building indoor and outdoor; existing problems; countermeasure analysis
\end{abstract}

\begin{abstract}
The environmental art design major is a major related to architectural design; it is an interdisciplinary comprehensive major and includes garden planning and design, garden engineering construction, space design, garden plant configuration and landscaping design, and indoor and outdoor decorative design, and the building indoor and outdoor design has relatively wide influence on environmental art design major. This paper briefly analyzes the problems existing in building indoor and outdoor environmental design teaching, and also carries out analysis on teaching measures about how to improve building indoor and outdoor environmental design.
\end{abstract}

\section{Introduction}

Due to continuous development and perfection of Chinese market economy, China's design industry has a direct development by leaps and bounds rather than gradual development, which results in the situation that many problems happen in the development process of China's modern design; those problems are not only reflected in social market economy, but also reflected in design education. Therefore, how to cultivate the environmental art design talents required by modern society is a problem which the education circle shall pay attention to.

\section{Problems existing in teaching of building indoor and outdoor environmental design}

\subsection{Students' weak basic capacity}

In recent years, the enrollment amount of most of schools is gradually expanded, and the number of students majoring in environmental art design increases. However, as for most of students majoring in environmental art design, they don't contact professional environmental art design knowledge; when they participated in college entrance examination, they just took an additional examination about basic art knowledge; therefore, they don't know what is building indoor and outdoor design at all. The environmental design major involves many contents, and the indoor and outdoor design part has included design, decoration, art, building, and other contents. Due to involvement of wide fields, students' art foundation and design capacity must be solid, and the students shall have high comprehensive quality and be able to develop a good learning habit, et. However, currently, most of students majoring in environmental design can't meet those requirements.

1.2. Improper teaching method for courses of environmental art design major

Currently, the teaching mode for most of courses of environmental art design major pays attention to studio teaching, and project teaching, etc. The building indoor and outdoor design course is a course with theoretical course nature and strong practice; however, it is common that most students majoring in environmental art design have weak practical operation ability in building indoor and outdoor design. When the school carries out teaching of building indoor and outdoor design course of environmental art design major, the teaching mode is partial to studio teaching and project teaching, and the teaching is carried out not according to individual feature of environmental art design major; furthermore, the students have a weak theoretical basic knowledge and don't have good case analysis ability, which results in the situation that it is unlikely for students to get control of operation ability of practice project, thus the students feel confused when they learn this professional course.

1.3. Few links between relevant course contents 
The curriculum system of environmental art design major involves many aspects. Generally, when the school establishes building indoor and outdoor course, it will firstly let students learn building theory, modeling foundation, design drawing and other basic professional courses; the teaching material content of this kind of basic courses has weak pertinence, which result in not close link among various courses of this major, thus it is hard to promote smooth implementation of successive courses. Meanwhile, as for the establishment of outdoor courses such as plant appreciation and landscape design, the coordination between teaching and practice is not handled well, thus the students can't find major orientation and can't establish clear objective when they face those different courses at the same time, and the students' learning effect on environmental art design major is imaginable. Besides, there are many kinds of teaching materials about environmental design art major, including partial construction, deflection, partial theory, construction, partial performance skills, etc.; however, the environmental art design major shall be "design thinking" oriented, thus the professional structure system of teaching materials of environmental art design major must be perfected.

\subsection{Unreasonable professional teaching curriculum provision}

Most schools don't clearly specify the training program for talents of environmental art design major, which makes students majoring in environmental art design unable to find the major objective and just determine the aim direction in an absent-minded way according to school teachers' guidance. For example, when the teachers make much guidance in building indoor and outdoor design course, the students will regard the building indoor and outdoor design as their own major; when the teachers make much guidance in landscape design course, students will think that their major is landscape design major. The objective of "one interface, two employment directions" is not implemented in true sense. In recent years, due to the fact that Chinese colleges and universities have basically implemented sharing of network resources, and built excellent building indoor and outdoor design course, etc., the building indoor and outdoor course of colleges and universities is similar in terms of teaching, and the teaching content is basically same, and the handing in practical teaching and theoretical teaching of professional course is not proper and scientific enough. Due to similar teaching content and teaching way adopted by colleges and universities in environmental art major, the environmental art major has a not obvious professional feature and weak pertinence, and lacks of features and individualities, thus the students don't have outstanding advantages after graduation and there is no strong competition between graduates of same major and same admission year. The building indoor and outdoor design course in environmental art design major is a course with strong comprehensiveness; therefore, when the teachers make course teaching of environmental art design major, the teachers must have rich professional knowledge, thus they can cultivate students' learning interest in professional course and make students get deep impression on this professional course. However, most of teachers don't meet this requirement; teachers don't have perfect knowledge structure, such as comprehensive science and engineering knowledge, garden knowledge, and art knowledge, and they are unfamiliar with or not proficient in professional skills such as modern art, modern engineering construction technology, and forestry, thus the students have weak professional technical capacity when they engage in the work related to major after graduation.

\subsection{Lack of relevant course practice}

The building indoor and outdoor design course in environmental art design major has strong art and technology property; the color and modeling are basic ability required for students, and the practical experience is also very important for students. In the actual teaching of environmental art design major, most of schools lack of establishment of practical link, and the specific reflection is shown as follows: the "double-capacity" professional academic advisor resource is deficient and the relevant practice bases are deficient, thus it is just empty talk of no avail as for theoretical teaching of environmental art major of various colleges and universities. Although some schools establish post practice platform for students and require students to take internship of professional courses in enterprises on vacation, due to interrupted time, such practice method can't make students get systematic knowledge of professional course. Meanwhile, the enterprises in which the students take 
internship are off campus and the sites are not centralized; the students are scattered to different places to take internship, thus the teachers can't give a tracking guidance for intern students; furthermore, the enterprises have no obligation to employ students or provide students with guidance, and some students even don't find the internship chance. Therefore, it is always difficult for the way of letting students make use of vacation time to autonomously take internship in off-campus enterprises always to play a good effect in cultivating students’ practice ability.

\section{Countermeasure analysis on teaching of building indoor and outdoor environmental design}

\subsection{To adopt scientific and reasonable teaching method in teaching}

When the teachers carry out teaching of building indoor and outdoor environmental art design, they shall adopt reasonable teaching method. For example: (1) it is able to "practice" the content when they carry out teaching of theoretical knowledge. In the teaching process of theoretical knowledge, the teachers shall specify their action orientation - target task in actual work, and take the professional knowledge and practice knowledge with strong practicability as key point of theoretical content teaching, as well as design relevant theory according to actual situation of social market so that the teaching of theoretical knowledge is not an armchair strategist any more; (2) the practical training teaching is carried out for students. When the teachers carry out course teaching of environmental art design major, they shall suitably carry out practical training teaching for students. Take building indoor and outdoor design course as an example: when the teachers carry out classroom teaching of project operation, they can group the students, let students form several project teams according to their own features, inform students that the practice unit is project team, and require the members of each group to complete project making according to their own strong points. For example, the students good at painting undertake the task of drawing, the students with good language competence are responsible for explaining the bidding of design scheme, and the students with strong design ability are responsible for scheme design so as to make classroom project teaching combined with actual project of enterprises, make students learn how to communicate with others in the process of team cooperation, and also improve students' practical ability; (3) to make the content become special. When the teachers carry out environmental art design teaching, they shall make special module for conceptual and rule theoretical knowledge so that the students can find out key points in course content, understand and master core content of knowledge points, thus the supporting training and teaching content become closely related and the theoretical knowledge has stronger practicality.

2.2. To carry out scientific and reasonable design for teaching content

The education circle shall design the teaching material content of environmental art design major in a reasonable way, and the content of different courses shall be relevant. Furthermore, the colleges and universities can prepare the teaching material content suitable for their students according to their own features. Take building indoor and outdoor design in environmental art design major as an example: its teaching content often has 4 projects, which have different emphases and different requirements for students; therefore, the teachers shall ensure the content relevance and continuity in teaching process. Project I: it requires that the students draw up the corresponding architectural plan according to their memory on their house, and the purpose is to let students understand the relation existing between people's behavior and architectural space, let students learn how to set the dimension of building space and how to analyze the ventilation and lighting requirement of building space, train students' memory and perception, and let students learn the basic method about design of building plane function layout. The project II is to let students learn how to design building plane; the building is a serviced apartment, with a width, depth, and storey height of $4.2 \mathrm{~m}, 8.1 \mathrm{~m}$, and $4.8 \mathrm{~m}$ respectively. The requirement is to carry out reasonable separation for apartment, divide furniture arrangement, two-layer space and use function, and the use function shall meet the requirements such as sleep or rest, entertaining guests, cleaning, dinning, and storage. The teaching purpose is to cultivate and enhance students' sense of spatial scale, cultivate students' overall sense of building space, and make students pay attention to influence factor which restricts the design, such as 
structure and equipments. The project III is to design tea room of the campus, and the design requirement is single-storey building; in design process, it is required to consider the condition of building base, human environment and other factors, and the purpose is to let students form a holistic view of building environment, help students establish a correct design principle concept such as human-oriented and sustainable development, and also cultivate students' ability in solving technical, formal, functional, and other problems and expressing modeling of building space. The project IV is to require students to design stand-alone small house, and the residence requirement is that the roof is flat or pitched roof, and the two-storey brick concrete structure building is regarded as subject design. Compared to other projects, this project is complicated in terms of structure, equipment, modeling, or building function, etc. The purpose is to make a systematic training for students, train students' ability to solve some common professional technical problems, and let students get a thorough understanding of basic concept of building environmental design according to scientific design principle.

2.3. To reasonable set professional teaching courses

When the teachers carry out teaching of environmental art design major, they shall carry out reasonable positioning for teaching course; in the positioning process, they shall consider the employment direction of this major, the standard of social market for such kind of professional talents, and talent requirements made under social development, etc. The art design and technology implementation of human settlement is the final direction of environmental art design major; on narrow sense, the human settlement includes two aspects of content, that is, indoor and outdoor. Therefore, it can be seen that the indoor design course is the foundation and core of this major with respect to indoor design; it has certain guidance function on students and can let students find out the employment direction of the major they learn in. when the school establishes this course, it shall arrange this course behind corresponding basic courses which include design basis, design drawing, and building theory so that the students can get hold of corresponding basic knowledge before they contact this course. Besides, the school shall cultivate "double-capacity” teachers, enhance teachers' self quality, and improve teachers' professional skills. As the executer in teaching activity, the teachers have obligation and responsibility to cultivate talents demanded by the society. Therefore, the colleges and universities shall improve teachers' teaching strength, encourage students to "step out”, and let teachers participate in various kinds of scientific research activities related to environmental art design major, improve their practice ability, supplement professional knowledge, accumulate teaching experience, and improve their own professional skills in extracurricular time.

2.4. To add practical teaching link

In order to let students intuitively know building in the source, the teachers shall establish practical teaching link in the classroom teaching as much as possible. For example, when the teachers carry out classroom teaching of environmental art design major, they can let students do various kinds of building models or construction models by themselves. The teachers can make proper grouping for students to let students jointly design drawing of building model and make building model in a mutually cooperative way. Through such practical teaching, it is able to enhance students' sense of dimension and scale, and let students' teamwork awareness improved. Besides, it is also able to make students measure building entity and draw the corresponding drawing according to actual situation.

\section{Conclusion}

The environmental art design major has strong creativity and practicalness; compared to other type of art design major, the environmental art design major pays more attention to cultivating students' practical design ability. Therefore, in the teaching process of environmental art design major, the teacher shall change the teaching way to realize effective cultivation of students' practical design ability so as to let students' professional skills meet social demand and let students develop the required talents. 


\section{Acknowledgments}

This paper is Heilongjiang educational science " $12^{\text {th }}$ Five-Year" plan project of 2012: Research on "Order-Oriented" Talents Training Mode of College Fine Art Major Based on School-Enterprise Cooperation; project No.: GBD1212080; and Mudanjiang Normal University education and teaching reform project: Research on Multi-dimensional Integrated Reform of Ice \& Snow Landscape Practice Teaching; project No.: 2013JGZX0059; Another is Mudanjiang Normal University education and teaching reform project: Research and Practice of Innovative Talents Training Mode of Fine Art Major Based on Industry-University-Research Cooperation; project No.: 12-XJ14076

\section{References}

[1] Yang Guanrong: Thought on Indoor Design Course Teaching of Environmental Art Design Major in Vocational Colleges [J], Education and Vocation, 2012

[2] Zhuang Yan: Preliminary Exploration on Building Design Course Teaching of Environmental Art Design Major [J], Jiangxi Architecture, 2009

[3] Liu Rui: Discussion on Environmental Art Design Teaching in Colleges and Universities [J], Divineland, 2012

[4] Huang Xin: Discussion on Teaching of Course Chinese and Foreign Architecture History in Environmental Art Design Major [J], Science \& Technology Association Forum, 2013

[5] Tang Haibo, Zhang Lili: Several Thoughts on Environmental Art Design Teaching [J], Heilongjiang Shiji, 2010 